ISSN 1045-6333

\title{
WHY ARE JAPANESE JUDGES SO CONSERVATIVE IN POLITICALLY CHARGED CASES?
}

\section{J. Mark Ramseyer}

Eric B. Rasmusen

Discussion Paper No. 268

$11 / 99$

Harvard Law School

Cambridge, MA 02138

The Center for Law, Economics, and Business is supported by a grant from the John M. Olin Foundation. 
JEL Class: K23, K41, J44

\section{Why Are Japanese Judges so Conservative}

\section{in Politically Charged Cases?}

\author{
J. Mark Ramseyer \\ Harvard University
}

\author{
Eric B. Rasmusen \\ Indiana University
}

Abstract: In politically charged cases, Japanese judges routinely implement the policy preferences of the longtime ruling Liberal Democratic Party (LDP). That Supreme Court justices defer to the LDP simply reflects the fact that they are appointed by the LDP at a senior level. We hypothesize that lower court judges defer on sensitive political questions because they then do better in their careers. In Japan, the lower courts couple a jurisdictional reach that includes politically sensitive disputes with a judicial career structure that rewards and punishes judges according to their work product. The result, we show, has been the politicization of basic judicial incentives.

To carry out this study, we assemble several new data sets. We then measure the quality of the assignments some 400 judges received after deciding various sets of politically charged cases, holding constant proxies for effort, intelligence, seniority, and political bias. Through this multivariate approach, we find that judges who defer to the LDP in politically salient disputes do better than those who do not. Similarly, judges who enjoin the national (but not local) government have less successful careers.

Last, to explore the use of other career penalties and to examine whether evidence of politically charged penalties appears in larger samples, we ask whether judges who joined a leftist group in the 1960s were promoted up the pay scale as rapidly as their peers. Using data on the 501 judges hired from 1959 to 1968 , we find that the leftist judges earned lower salaries.

Note: Ramseyer (corresponding author) is Mitsubishi Professor of Japanese Legal Studies at Harvard University Cambridge, MA 02138. Email: Ramseyer@law.harvard.edu; phone: (617) 496-4878; fax: (617) 496-6118. Rasmusen is Professor of Business Economics and Public Policy at the Kelley School of Business, Indiana University, 1309 East Tenth Street, Bloomington, Indiana 47405-1701. Email: Erasmuse@indiana.edu; phone: (812) 855-3356; fax: (812)855-3354. Php.Indiana.edu/ erasmuse. We received helpful comments and suggestions from Christine Jolls, Dennis Karjala, Mark Levin, Kip Viscusi, Mark West, and participants at workshops at Indiana University, Kyushu University, the Law and Society Association, the National Bureau of Economic Research, and the Comparative Law \& Economics Forum. Ramseyer gratefully acknowledges the generous financial assistance of the John M. Olin Program in Law, Economics, \& Business, Harvard University. 


\title{
Why Are Japanese Judges so Conservative in Politically Charged Cases?
}

\author{
J. Mark Ramseyer Eric B. Rasmusen \\ Harvard University Indiana University
}

(C)1999 J. Mark Ramseyer and Eric B. Rasmusen. All rights reserved.

"All judges are independent in the exercise of their conscience and bound only by this Constitution and the laws."

---Article 76, section (3), Constitution of Japan

In politically charged cases, Japanese courts are brutally conservative machines. In dealings with the government, Japanese judges routinely agree that what the government has done is legal. That the Supreme Court seldom voids statutes is legendary. Although lower courts defer slightly less, they too tend to parrot the moderately conservative positions of the longtime incumbent Liberal Democratic Party (the LDP).

In this article, we explore the institutional reasons for this judicial deference. Why the Supreme Court justices would uphold LDP positions is straightforward -- after all, for most of the post-war period they have been recent LDP appointees. Why lower court judges would uphold LDP positions is less obvious, since the government appointed them straight out of law school with relatively little information about their political leanings. All else equal, the government should often have found itself saddled with at least a substantial minority of heterodox judges. The occasional heterodox opinion would have followed as a matter of course.

Yet heterodox opinions generally did not follow. In this article, we use the career structure of the courts to explain why they did not. Using systematic, newly assembled data on judicial 
careers (about 400 judges), we explore the impact that a public-law opinion has on a judge's career. We first locate several proxies for a judge's seniority, intelligence, effort, and ideology. We then hold constant those proxies, and examine the careers of (i) judges who held either the Self-Defense Force (the SDF) or U.S. bases unconstitutional; (ii) judges who rejected national electoral apportionment schemes advantageous to the LDP; and (iii) judges who most often enjoined the national government in administrative law suits. Systematically, we find that they suffered in their careers.

We conclude by exploring whether judicial salaries are correlated with political affiliation. Toward that end, we study the impact that joining a leftist organization had on the pace at which a judge climbed the pay scale. From Japanese sources, we have newly assembled career data on all judges hired between 1959 and 1968, about 500 judges. aWe find that in this population of judges, the leftist judges were promoted more slowly than their conservative peers.

We know of no other study that uses a multivariate approach to test systematically the effect of a variety of politically charged opinions on Japanese judicial careers. Although a few studies have used career data to test for Japanese judicial independence in other settings (criminal and tax cases, for example), this article is the first to use such data to study judicial independence in range of disparate but politically sensitive disputes. It is also the first to test for a political bias in pay. Despite increasing scholarly interest in the empirics of judicial independence, analogous studies in other countries have been rare as well, as surveyed in Ramseyer (1998).

Ramseyer (1994, 1999) has already written extensively on why, given the political and institutional framework in Japan, close political oversight of judges is what one would expect if politicians were not restrained from intervention by internal norms of duty or fairness (Ramseyer 1994, 1999). In the present article, we examine those predictions using quantitative analysis of 
empirical data. We begin by reviewing the literature on public-law litigation in Japan (Section I). We then outline the institutional structure of the courts (Section II), explore the connection between public-law opinions and judicial careers (Section III), and conclude by testing whether leftist judges were promoted more slowly than their colleagues (Section IV).

\section{Public-Law Litigation:}

\section{A. The Supreme Court:}

The Japanese Supreme Court is deferential in the extreme. To be sure, even the U.S. Supreme Court does not invalidate legislation as a matter of course. Yet as of 1993, according to one scholar the Japanese Supreme Court denied the validity of legislation on constitutional grounds only a half-dozen or so times in its entire history. ${ }^{1}$ The reason is relatively straightforward. As most observers rightly note, almost all the justices have been recent LDP appointees, and the party passing the legislation has also been the LDP. ${ }^{2}$

Compare this with the United States. Given frequent political turnover between Republicans and Democrats, U.S. Presidents regularly try to stack the Supreme Court with relatively young justices to take advantage of lifetime tenure. This produces the motley ideological Supreme Court composition that Americans take for granted: the Court includes both Democrat and Republican justices, and, since they often serve 20 years or more on the Court, it includes justices who have switched political allegiance since they were appointed.

LDP leaders in Japan faced a different political scene. During most of the period, the leaders tightly controlled the party; the party controlled the national legislature, the Diet; and there

1 See Okudaira (1993, p. 20); Haley (1998, pp. 179-80); Tomatsu (1993, p. 194). Compare this with the some 124 statutes declared unconstitutional in the U.S. (Witt 1990, pp. 1001-09 [124 ]). 
was little chance of any other party coming to power in the near future. Virtually all justices except for a few carryovers from Katayama's short-lived Socialist cabinet of 1947-48 were conservative appointees. Given that the LDP expected to stay in power and continue appointing justices indefinitely, the LDP leaders could afford to appoint justices late enough in life (generally in their early 60 's) that the justices would be unlikely to change their views before mandatory retirement at age 70 (Ramseyer and Rosenbluth 1993, ch. 8). As a result, judicial review in the Japanese Supreme Court involved the review of LDP-sponsored legislation by recent LDP-appointees.

In appointing Supreme Court justices, the Prime Ministers have, to be sure, largely rubberstamped nominees selected by a group within the career judiciary, but this matters not a whit to the logic just described. The career judiciary only nominated people they knew the Prime Ministers would approve. For evidence note that several post-war Supreme Court justices came from the bar and the universities, but hardly as a random sample of talented lawyers. During much of the period, these groups, and particularly university faculties, were heavily Marxist. Had the nominating judges looked only to raw talent, they would regularly have nominated Marxists for the Court. In fact, neither of us has ever met anyone who suggested that a single Supreme Court justice appointed during the long LDP tenure was Marxist. The logic is simple: the Prime Minister rubber-stamped the nominees only because it was so easy for him to have rejected them if he had wanted to. Because the nominating judges knew he could reject their suggestions readily, they would not have wasted time proposing leftist Supreme Court nominees even if they had sympathized with the left.

\footnotetext{
${ }^{2}$ E.g., Okudaira (1993, p. 24). Note, too, that courts in a parliamentary system will generally tend to be more
} 


\section{B. The Lower Courts:}

The real puzzle is not the Supreme Court's conservatism, butthat of the lower courts': the over 2,000 judges in the district courts, high courts, and family courts. ${ }^{3}$ While not as uniformly deferential as the Supreme Court, these judges too have tended to side with the government. Yet unlike U.S. federal judges, Japanese lower court judges are not appointed as middle-aged workaholics with verifiable political credentials. Instead, they are ordinarily appointed in their late 20s, straight out of the national law school (the Legal Research \& Training Institute, the LRTI). Even had they wished, LDP leaders would have found it hard to predict what a young appointee's political beliefs would be, and especially to predict what they would be thirty years later when he was a senior judge.

From time to time, observers have tried to explain this deference in the lower courts by the pre-War autocratic legacy or the purportedly greater deference in civil-law judiciaries generally. Yet neither explanation works. Modern Japanese politics and government differ radically from pre-war politics and government. To use the pre-war legacy to explain modern judging, one would have to explain why it affects this aspect of modern government but not other aspects. Similarly, some modern European courts defer to the government less than Japanese courts, notwithstanding their shared civil-law tradition. Before we can cite civil-law universals to explain modern Japanese deference, we need to know why the European tradition shapes Japanese judges more than it shapes judges on its home turf.

conservative than in a presidential system, for reasons explained in Ferejohn (1995, pp. 208-209).

${ }^{3}$ John Haley $(1995,1998)$ argues that Japanese judges defer to the government out of a desire to implement policies preferred by the majority of Japanese citizens. In most (not all, as we discuss below) cases, that hypothesis is observationally equivalent to our own. It is precisely because a majority (or sometimes a plurality) of Japanese voters preferred modestly capitalist policies that they consistently elected the LDP -- such things as the fiddling with apportionment that we discuss in this article were marginal, though very important to certain individuals in the LDP. As a result, in implementing LDP policies (our hypothesis), Japanese judges also implemented the preferences of a large swathe of Japanese voters (Haley's hypothesis). 


\section{The Structure of the Courts:}

\section{A. Appointment and Reappointment:}

A reason for Japanese lower-court deference might lie in the internal structure of the courts. ${ }^{4}$ Once appointed, an American federal trial judge has a job for life. Absent egregiously bad behavior or senility -- and perhaps even then -- he can work as long as he wants. Unless he quits by choice or finds himself promoted to the Court of Appeals, he will sit in the same court in the same city for his entire judicial career, and collect the same salary as every other federal trial judge.

By contrast, after his initial appointment a Japanese judge will find himself reassigned every few (generally three) years. Perhaps during his first three years he will work as a trial judge in the Osaka District Court. He may then find himself transferred first to the Sendai High Court, then to the family court branch office in Miyazaki, and then to the Ministry of Justice in Tokyo. He may spend a stint teaching at the LRTI or working in the Secretariat, the administrative offices of the court system. So long as he is reappointed every ten years, which virtually everyone is, he is guaranteed some job in the judiciary until age 65 . Yet the quality of this job, and perhaps even the pay he receives, depends on how the judges at the Secretariat (staffed itself by fast-track judges) rate his work. Although they may not constitutionally cut his base salary, they face no obligation to move him up the pay scale at the same rate as everyone else or to give him important jobs.

The potential incentive effects follow. By all accounts, most Japanese judges find administrative duties prestigious and branch office assignments embarassing. Like the vast majority of other professionals, they want to live in Tokyo if possible, and in Osaka if not. Like the vast majority of humans, they prefer higher pay to lower. The fact that prestige, geography, and pay 
depend on performance should tend to induce them to work hard and carefully -- and by all accounts they usually do.

At least indirectly, this system has the potential for political manipulation. After all, LDP Prime Ministers do appoint moderately conservative justices to the Supreme Court; those justices do supervise the Secretariat; and on the Court is usually at least one justice who has previously headed the Secretariat and knows its workings intimately. The Secretariat, in turn, decides which judges will go to what cities, who will hold which prestigious administrative jobs, who will spend how many years in branch offices, and who will climb the pay scale at what rate.

In this article, we ask whether LDP leaders actually do use this potential influence for political ends. Although judicial pay is confidential, geographical and administrative postings are not, and some administrative postings are available only to judges at certain pay grades. Other research has explored some of the determinants of geographical assignments (Ramseyer and Rasmusen 1997). In the article that follows, we continue this exploration of the determinants of administrative and branch office postings, and extend it to the determinants of judicial salary as well.

\section{B. Political Bias:}

In other contexts, all else equal, research has shown (Ramseyer and Rasmusen 1997, 1998, 1999): that judges who joined a communist-leaning bar organization (the Young Jurists League -YJL) in the 1960s had fewer administrative postings than those who did not join; that judges who consistently convicted criminal defendants spent less time in branch offices than those who occasionally acquitted; that judges who found their tax opinions reversed on appeal had fewer

\footnotetext{
${ }^{4}$ Below, we limit ourselves to a short summary of that institutional structure. For more detail and for citation
} 
administrative assignments and more branch office postings than those without such reversals; and that judges who held a ban on door-to-door canvassing unconstitutional suffered in their careers.

Of these, the last is the most relevant to the present article. Because incumbents have free air time by being incumbents, a ban on canvassing helps incumbents and hurts challengers. Because the LDP had the most incumbents, the ban helped the LDP and hurt the smaller parties -- as one might expect of a ban passed by an LDP Diet. From time to time, opposition candidates challenged the ban in court. Consistently, the Supreme Court held it constitutional. From time to time, however, a few lower court judges held the contrary. When they did, they suffered in their careers. In the present article, we ask whether this result generalizes to other politically charged sets of public-law disputes.

\section{Public-Law Litigation in Japan:}

\section{A. Introduction:}

To study systematically the effect of public-law opinions on judicial careers, we need disputes that involve large numbers of judges. Even disputes involving only one or two lower-court panels do provide some anecdotal evidence of political influence. And both in Japanese and English, several scholars have detailed a variety of such anecdotes (Haley 1998, ch. 5; Kashimura 1991; Miyazawa 1991; Ramseyer 1994; Ramseyer and Rosenbluth 1993, chs. 8-9; Sakaguchi 1988; Tsukahara 1991). But although the anecdotes suggest that judges who flout the political preferences of the LDP receive worse assignments, by their nature anecdotes remain inconclusive.

The problem is that too many judicial transfers have nothing to do with politics. Many are simply random. The Secretariat worries that judges might go on the take from the mob, and the 
easiest way to reduce corruption is to move judges regularly. Many transfers are simply incentives for effort. The Secretariat cares whether judges work or shirk, and the easiest way to induce effort is to reward those who produce. As a result, even the most pro-LDP judge risks spending time in branch offices and provincial cities. It is the very routineness of reassignment that gives the camouflage which makes political pressure feasible without worry of public outrage. Imagine a judge who writes a prominent heterodox opinion and finds himself banished to three years in the outback. He might have gone there because the Secretariat hated the opinion. He might have gone there because he was lazy. Or he might have gone there out of sheer dumb luck. Most likely, he and those who dislike the LDP will claim the first reason is the real one, but other people are understandably skeptical.

To determine whether the Secretariat uses job assignments to punish and reward judges for the opinions they write, we need a systematic multivariate approach. Accordingly, in this study we focus on disputes for which a relatively large number of judges wrote opinions. We then code the opinions by a political metric and by whether they were reversed on appeal and ask whether judges' decisions help explain the appointments they receive. More precisely, we estimate the quality of a judge's post-public-law opinion job postings, denoted JOB, through a regression equation,

$$
\mathrm{JOB}=\mathrm{a}+\mathrm{B}_{1} * \text { OPINIONS }+\mathrm{B}_{2} * \text { CONTROLS }+\mathrm{e} .
$$

OPINIONS is a vector of variables that describe the judge's public-law opinion -- whether it followed LDP policy, for example, whether it favored the government, or whether it was reversed on appeal. CONTROLS is a vector of control variables that proxy for the judge's seniority, ideology, effort, and intelligence. Other research finds that these variables affect the quality of the jobs judges receive (Ramseyer and Rasmusen 1997). We control for such variables here lest we confuse the effect of the public-law opinions with coincidental talent, experience, or political bias. 
We assemble our data from several sources. For judicial opinions, we rely on the Hanrei

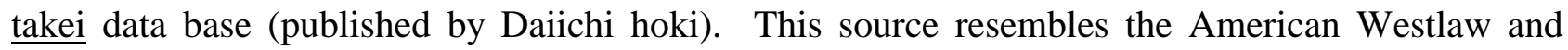
Lexis, and includes virtually all post-War published opinions on nine or ten CD-ROMs. For judicial careers, we use the Zen saibankan keireki soran (ZSKS), a book that details all job postings received by judges educated after the Second World War. For membership in the leftist YJL as of 1969, we use a book called Osorubeki saiban -- which in turn copied the list from the League's own newsletter (Shiso 1969).

As background, note several points. First, Japanese courts do not use juries. All trials are bench trials, with the judges deciding questions of fact as well as questions of law. Second, most trials are conducted by three-judge panels -- routine non-serious criminal trials are the exception. Third, lower-court (but not Supreme Court) opinions are signed by the entire panel. Even if a judge dissents, he does not publicly disclose that fact.

Although we base our conclusions on results that are statistically significant at the 10 percent level or better, readers should take our results with caution. Very few judges flout the LDP. We found 47 judges who ruled on Article 9 of the Constitution (discussed below), for example, but only five of them held the military unconstitutional. We found 89 judges who addressed electoral districting rules, but only seven who struck down the rules before the crucial 1984 opinion that we discuss below. The problem with this is that we may have omitted some variable that is the real explanation for the heterodox judges' damaged careers. At least hypothetically, those judges who flouted LDP policies could also have shared some characteristic correlated with unsuccessful careers but not captured by our control variables. The judges who held the military unconstitutional might, for example, have happened to be bald, overweight, and divorced, and the Secretariat could have maintained a bias against bald fat divorced judges -- which was the real reason for their poor 
career performance. Given our lack of explicit control variables for such characteristics, perhaps some such combination of factors explains the punishment we observe. ${ }^{5}$

It is precisely because of the small number of heterodox judges in some of our samples, however, that we repeat the tests on several independent data sets. Note several points. First, in all politically sensitive sets of cases below, we obtain statistically significant results. Second, related studies have found significant punishment of judges who hold unconstitutional the ban on door-todoor canvassing, who acquit criminal defendants, or who find their tax opinions reversed on appeal. Last, not all our tests involve the punishment of a small number of judges. Among the 130 judges who ruled on petitions for preliminary injunctions, 42 enjoined the national government. And in Section IV below, we find evidence of pay discrimination against the 140 leftists among all 500 judges hired between 1959 and $1968 .^{6}$ To us at least, this uniformity across a wide variety of data sets suggests that we capture more than a statistical anomaly.

In the rest of Section III, we consider five types of cases: (1) Article 9 cases, involving the military, (2) malapportionment cases, (3) injunctions against local and national government, (4) constitutional cases generally, and (5) commercial cases.

\section{B. Article 9 -- The Self Defence Force:}

1. The cases. -- Let us begin with what is the best-known constitutional dispute in Japan: the argument over Article 9 of the Constitution. On its face, Article 9 proclaims that "land, sea, and air forces, as well as other war potential, will never be maintained." By any but the most tortured

5 Note, however, that our PRIOR_GOOD_JOBS and PRIOR_BAD_JOBS variables will captured much of the effect of even those factors-- we will be looking not just for bad careers, but for careers that become worse. It would only be judges who became fat, bald, and divorced in about the same year as their decision striking down the military who would cause trouble for our technique.

${ }^{6}$ The claim (at Haley 1998, p. 107) that "most" of the YJL members "quietly resigned" is misleading. They 
interpretation, this would ban the Self-Defense Force (SDF); the LDP always has claimed it did not. By no stretch of the imagination could Douglas MacArthur, godfather of the clause, have thought it banned U.S. bases; occasionally, the opposition has said it did.

Periodically since the 1950s, the Supreme Court has faced challenges to the Self Defence Force and American bases. Each time, it has refused to hold either unconstitutional (Beer 1996; Auer 1993). From time to time, however, lower-court judges have done just that. We found 25 district court opinions addressing Article 9, three of which held either the Self Defence Force or the bases unconstitutional. Excluding unsigned opinions, judges who do not appear in the ZSKS (generally judges educated before the war), and judges with less than 1-1/2 years of experience before or 2-1/2 years' experience after the opinion, we obtain a sample of 47 judges who wrote opinions on Article 9, 3 of whom wrote 2 opinions each. To avoid improperly weighting judgespecific effects for these three judges, we include dummy RHS variables for each.

2. The variables. -- For each judge we construct (a) two alternative JOB variables that measure the quality of jobs the judge held over the decade after the Article-9 opinion (POST_GOOD_JOBS and POST_BAD_JOBS), (b) an OPINION variable that gives the judge's decision in the Article-9 opinion itself (UNCONSTITUTIONAL), and (c) a series of CONTROL variables that proxy for intelligence, effort, seniority, and ideology. Because the Supreme Court consistently held the SDF and bases constitutional, we do not include a variable specifying whether the Supreme Court reversed the opinion. Below, we describe these variables and note the effects predicted by previous research (Ramseyer and Rasmusen 1997, 1998, 1999). Table 1 shows the summary statistics.

[Insert Table 1 about here.] 
(a) Dependent variables.

POST_GOOD_JOBS: the percentage of time during the decade after the Article-9 opinion in which a judge held prestigious appointments -- either as chief judge, with sokatsu (largely personnel) responsibilities, or in another administrative post.

POST_BAD_JOBS: the percentage of time during the decade after the opinion in which a judge was in a branch office (other than the relatively desirable Hachioji office).

Because these dependent variable are censored, only taking values between 0 and 100, we use tobit rather than OLS in our regressions. Note that POST_GOOD_JOBS and POST_BAD_JOBS will not sum to 100 for an individual judge, because not all jobs are good or bad -- most are mediocre. Our interest here is in carrots and sticks, not in benign neglect.

(b) Decision variable.

UNCONSTITUTIONAL: 1 if a judge held either the Self Defence Force or U.S. bases unconstitutional; 0 otherwise.

(c) Control variables.

PRIOR_GOOD_JOBS: equivalent to POST_GOOD_JOBS for the decade before the opinion. We use it on the right-hand side to capture otherwise unobserved information about the judge's position within the judicial hierarchy (and thereby to mitigate the potential omitted variable issue discussed earlier). Because fast-track judges will generally stay on the fast track (and slowtrack judges on the slow), PRIOR_GOOD_JOBS usually correlates positively with POST_GOOD_JOBS.

PRIOR_BAD_JOBS: equivalent to POST_BAD_JOBS for the decade before the opinion. Generally, PRIOR_BAD_JOBS correlates positively with POST_BAD_JOBS. 
SENIORITY: the number of years between the opinion and the year a judge graduated from the LRTI. In general, the more senior the judge the better the job he will have. As a result, SENIORITY generally correlates positively with POST_GOOD_JOBS and negatively with POST_BAD_JOBS.

FLUNKS: the estimated number of years (based on birth year) between college graduation and entrance to the LRTI. Because the LRTI entrance exam passage rate varied between 1 and 4 percent, even the best students usually failed it several times. By approximating the number of times a judge failed this exam, FLUNKS inversely proxies for IQ and effort. Because smarter and harder working judges tend to be more successful than others, FLUNKS usually correlates positively with POST_BAD_JOBS and negatively with POST_GOOD_JOBS.

ELITE_COLLEGE: 1 if a judge graduated from either the University of Tokyo or the University of Kyoto; 0 otherwise. Because the variable proxies for IQ and effort (and captures any old-school ties), ELITE_COLLEGE will generally correlate positively with POST_GOOD_JOBS and negatively with POST_BAD_JOBS.

OPINIONS/YR: a judge's average productivity (measured in published opinions per year on the bench) for the decade before the opinion. Given that observed productivity will correlate with intelligence and effort, OPINIONS/YR will positively correlate with POST_GOOD_JOBS and negatively with POST_BAD_JOBS.?

15T_TOKYO: 1 if a judge started at the Tokyo District Court; 0 otherwise. When the Secretariat hires a new class of judges it generally assigns the most promising to the Tokyo District Court. Because fast-track judges tend to stay on the fast-track, $1^{\mathrm{ST}}$ TOKYO tends to correlate positively with POST_GOOD_JOBS and negatively with POST_BAD_JOBS. 
YJL: 1 if a judge was a member of the Young Jurists League in 1969; 0 otherwise. To the extent that the Secretariat has continued to punish former YJL members, YJL will correlate positively with POST_BAD_JOBS and negatively with POST_GOOD_JOBS.

Precisely because the Secretariat starts the most promising judges at the Tokyo District Court, the coefficient on $1^{\text {ST }}$ TOKYO will include an indirect effect of both FLUNKS and ELITE_COLLEGE. Consider the 501 judges hired between 1959 and 1968, the data set used in Section IV below. Regressing $1^{\mathrm{ST}}{ }_{-}$TOKYO on the relevant RHS control variables using probit, we obtain coefficients of -.102 on YJL (with a z statistic of 0.55 ), -.146 on FLUNKS (z of 4.23), and .682 on ELITE_COLLEGE ( $\mathrm{z}$ of 4.08), with a pseudo R-squared of 0.15 . This means that the effects of FLUNKS and ELITE_COLLEGE on $1^{\mathrm{ST}}$ _TOKYO are both statistically significant at the 1 per cent level, but YJL had no significant effect, perhaps because the membership was not public knowledge until 1969 (after the judges in the data set had their first posting). The low R-squared of .15 indicates that FLUNKS and ELITE_COLLEGE are by no means a guarantee of a good first posting, however, explaining less than 15 percent of the variance.

[Insert Table 2 about here.]

3. The results. -- Table 2 reports our results. What is most important is that the UNCONSTITUTIONAL coefficient of -.397 in the POST_GOOD_JOBS regression is negative and statistically significant. Compared to judges who held the Self Defence Force or U.S. bases constitutional (or who otherwise ducked the issue), those who held either unconstitutional received fewer prestigious administrative duties in the decade after the opinion.

The UNCONSTITUTIONAL coefficient on POST_BAD_JOBS is not statistically significant. When the Secretariat punishes judges, it could use either longer branch-office

\footnotetext{
${ }^{7}$ Ramseyer and Rasmusen (1997, p. 272) notes that a low OPINIONS/YR score is more properly a cause of
} 
assignments or shorter administrative appointments. Here, it seems the Secretariat cares more about avoiding putting the erring judges in administrative appointments.

Where statistically significant, the control variables all have the predicted signs. Thus, PRIOR_GOOD_JOBS has a significant and positive effect on POST_GOOD_JOBS: the more administrative responsibilities a judge had before deciding the Article 9 case, the more he had afterwards. SENIORITY and ELITE_COLLEGE are also significant; administrative responsibilities tended to go to the more senior judges and to those from the Universities of Tokyo and Kyoto, even beyond the effect these things might have had on the judge's career prior to the Article 9 decision. POST_BAD_JOBS does not seem to depend on PRIOR_BAD_JOBS, surprisingly, but it does depend on OPINIONS/YR and ELITE_COLLEGE; judges with Kyoto and Tokyo degrees and those who published more opinions spent less time in branch offices.

\section{Malapportionment:}

1. The disputes. -- Electoral apportionment is a chronic issue in Japanese courts. Through the 1960s and into the 1970s, the LDP relied heavily on the rural vote. During that time, however, Japanese families were steadily migrating to metropolitan centers. As a result, the LDP gained by stalling reapportionment. By keeping the old apportionment rules, it maximized the number of representatives from heavily LDP rural districts.

Increasingly, LDP leaders recognized that delaying reapportionment was a bad strategy for the long term. Sooner or later, they would have to reposition their party away from the farm vote and create a new identity as a party for urban consumers. Naturally, many in the LDP rank-and-file, particularly Diet members from the rural districts, fought this change. For the LDP, the 1970s and 
1980s were a time of internal turmoil -- a time of tension between the leaders who would eventually lose their power if the party did not reposition itself and rank-and-file members who would immediately lose their jobs if it did (Ramseyer and Rosenbluth 1993, ch. 3).

Faced with challenges to the existing apportionment schemes, the Supreme Court wrote opinions that generally tracked the positions of the LDP leaders. During the first period, the Court rejected challenges to the overrepresentation of rural voters. In the 1976 case of Kurokawa v. Chiba,${ }^{8}$ however, it switched sides. By this point, the LDP leaders were pushing the party to jettison the agricultural vote. Faced with plaintiffs who claimed that some votes counted five times as heavily as others, the Court held the apportionment unconstitutional -- thereby helping out LDP leaders who would have found it more difficult to force LDP Diet members to redistrict themselves out of jobs without judicial pressure. In 1985, with Kanao v. Hiroshima the Court reiterated the point: rural overrepresentation was unconstitutional. ${ }^{9}$ By then, LDP leaders were solidifying the party's position as an urban party and abandoning the farmers to the socialists and communists. The Supreme Court dutifully followed -- and held the rural overrepresentation unconstitutional.

Given this shift in the position of the LDP leadership and the Supreme Court, one would not expect the Secretariat to have always punished judges for holding apportionment rules unconstitutional. ${ }^{10}$ Instead, one would expect it to punish a judge only if either (i) the judge held an

\footnotetext{
${ }^{8}$ Kurokawa v. Chiba ken senkyo kanri iinkai, 808 Hanrei jiho 24 (Sup. Ct. Apr. 14, 1979) (en banc), rev’g 30 Saihan minshu 288 (Tokyo High Ct. Apr. 30, 1974); see Haley (1998, pp. 179-80).

${ }^{9}$ Kanao v. Hiroshima ken senkyo kanri iinkai, 1163 Hanrei jiho 3 (Sup. Ct. July 17, 1985 (en banc), aff'g 1134 Hanrei jiho 27 (Hiroshima High Ct. Sept. 28, 1984). The Court needed more than one opinion to make the point forcefully because of the fact-specific nature of the problem. The Court did not require that every vote have exactly the same effect, and thus needed several opinions to clarify just how much variation in electoral power it would allow.

${ }^{10}$ And it did not. When we create a general variable equalling 1 if a judge held any apportionment scheme improper and run a regression with the same control variables as in Table 4, we obtain coefficients and t-statistics of .040 (0.24) (for the POST_BAD_JOBS regression) and .018 (0.21) (for the POST_GOOD_JOBS regression); the effect on careers of striking down rural overrepresentation averaged over the entire period is nil. But that is like saying that if one averages together the Gulf War and the Kosovo War, the U.S. Democratic Party does not take any position on foreign intervention.
} 
apportionment scheme unconstitutional prior to the lower court opinions in Kurokawa (1974) and $\underline{\text { Kanao }}$ (1984), or (ii) the judge held an apportionment scheme unconstitutional and found that opinion reversed on appeal. To test these hypotheses, we assemble a new data set and define several additional variables. Summary statistics appear in Table 3.

[Insert Table 3 about here.]

2. Data and variables. -- The data set begins with the 69 lower court opinions that raised the propriety of electoral apportionment schemes, whether on constitutional or statutory grounds. By law, most electoral challenges begin at the High Court level, so the judges in this sample will already be in somewhat prestigious positions at the time of their decisions. Excluding unsigned opinions and judges whose career data did not appear in the ZSKS or who had less than 1-1/2 years' experience before or 2-1/2 years' experience after the opinion, we were left with a set of 89 judges (8 of whom wrote 2 opinions -- for whom we again use judge-specific dummy variables). Of the cases, 54 involved challenges to national elections and 15 to local elections. We then defined the following variables.

INVALID $\leq 73: 1$ if a judge held a national apportionment scheme ${ }^{11}$ illegal prior to the 1974 trial court opinion in Kurokawa; 0 otherwise.

INVALID $\geq 74: 1$ if a judge held a national apportionment scheme illegal in or after the 1974 trial court opinion in Kurokawa; 0 otherwise.

INVALID $\leq 83: 1$ if a judge held a national apportionment scheme illegal prior to the 1984 trial court opinion in Kanao; 0 otherwise.

${ }^{11}$ We also ran the first four regressions in Table 4 using a variable that combined judges involved in all apportionment challenges, whether local or national. Because (for reasons detailed below in the context of preliminary injunctions) many local electoral schemes benefited parties other than the LDP, one would expect the effect to be less pronounced. The coefficients and t-statistics on a variable equal to 1 if the judge held improper any (national or local) pre-Kurokawa apportionment scheme were 1.32 (2.81) (PRIOR_BAD_JOBS) and -.689 (2.07) (PIOR_GOOD_JOBS); 
INVALID $\geq 84: 1$ if a judge held a national apportionment scheme illegal in or after the 1984 trial court opinion in Kanao; 0 otherwise.

INVALID.REV: 1 if the Supreme Court reversed a judge's opinion holding a national apportionment scheme illegal; 0 otherwise. ${ }^{12}$

VALID.REV: 1 if the Supreme Court reversed a judge's opinion holding a national apportionment scheme legal; 0 otherwise.

[Insert Table 4 about here.]

3. The results. -- The results, shown in Table 4, confirm both sets of hypotheses. First, judges who held a national apportionment scheme improper during the years when the LDP depended on the rural vote found themselves punished. The variable INVALID $\leq 83$ in Regression (4.3) is significant and has a positive effect on POST_BAD_JOBS. During these early years, if a judge held the apportionment scheme improper, he spent more time in branch offices after the opinion. ${ }^{13}$

We find no evidence of any punishment against judges who held the schemes improper after that time, however; INVALID $\geq 84$ is insignificant. Note also that the punishment seems to have operated mainly through more branch office time rather than less time in prestigious postings; the coefficients on POST_GOOD_JOBS are insignificant, though with the predicted signs.

Second, if the Supreme Court reversed a judge's opinion invalidating an apportionment scheme, the Secretariat punished the judge, no matter whether that happened before 1984 or after. The variable INVALID.REV in Regressions (4.5) and (4.6) has a significant positive effect on

for pre-Kanao apportionment schemes, they were 453 (1.86) (PRIOR_BAD_JOBS) and -.046 (.30) (PRIOR_GOOD_JOBS).

${ }^{12}$ Here and elsewhere in this study, some appeals were hard to classify as affirmances or reversals. In such cases, we looked to the substance of the opinion and tried to capture the gist of the appellate decision. 
POST_BAD_JOBS and a significant negative effect on POST_GOOD_JOBS. If a judge found his opinion invalidating an apportionment scheme reversed, he spent more time in branch offices and less time with administrative responsibilities.

Where significant, the control variables again have the predicted effect. SENIORITY has positive effect on POST_GOOD_JOBS: the more senior the judge, the more time he spent with administrative responsibilities. ELITE_COLLEGE has a negative effect on POST_BAD_JOBS: judges from the Universities of Tokyo and Kyoto spent less time in branch offices. The effect of a high value of OPINIONS/YR is positive for POST_GOOD_JOBS and negative for POST_BAD_JOBS: the most productive judges spent the most time with administrative responsibilities and the least time in branch offices.

This set of regressions helps resolve an issue that the Article 9 regressions could not address. One explanation for the Article 9 regressions could be that the Secretariat was run by judges who, although completely independent from LDP pressure, were generally conservative politically and in judicial temperament, and hence were reluctant to use Article 9 to weaken national defense. Conservative politics and temperament, however, would not explain a Secretariat that was not bothered by rural overrepresentation until 1984 but favored striking it down after that. Our results suggest, to the extent that our limited sample can be trusted, that the judicial system was following the beliefs of the LDP leadership, not of the average LDP Diet member.

D. Preliminary Injunctions:

\footnotetext{
${ }^{13}$ The effect is even stronger for the very earliest opinions (INVALID $\leq 73$ ), but we do not base our analysis on
} 
1. Introduction. -- In administrative litigation, if a plaintiff can show the potential for irreparable harm, he can demand a preliminary injunction against the government. ${ }^{14}$ Does a judge risk his career in granting it?

We would not expect a judge to find his career jeopardized if he decides a routine administrative case against the government. ${ }^{15}$ Like any elected government, to stay in office the LDP has more to do than just enact the policies voters want -- it must also deliver the policies. For that, it needs the set of agents we call bureaucrats. Like other humans, however, bureaucrats tend to shirk their duties and ignore instructions unless they are disciplined. To the extent that bureaucrats shirk, voters complain and the elected officials risk losing office. To make bureaucrats deliver the policies that the LDP has enacted and that voters want, the LDP should encourage citizens who encounter lazy, ineffective, or law-breaking bureaucrats to sue them in court (McCubbins and Schwartz 1984). And for that mechanism to work, the LDP needs a cohort of relatively unbiased and accessible judges.

The LDP therefore facilitates legal challenges in routine administrative cases as a way to hold bureaucrats in check. First, Japanese "standing" rules generally permit challenges to those bureaucratic decisions that are too minor to warrant direct intervention by the LDP or the local Diet representative. ${ }^{16}$ Second, to insure an impartial forum in these ordinary administrative disputes, the

that because of the small number of observations.

${ }^{14}$ Gyosei jiken sosho ho, Law No. 139 of 1962, § 25.

${ }^{15}$ See Ramseyer and Rasmusen (1999). There, the data show that judges who rule against the government in tax cases are not hurt in their careers. This makes sense even if the government is entirely dominated by partisan politics. In short: if the government wants to get more revenue from taxpayers, it can simply rewrite the tax laws; what the government wants judges to do is to interpret the existing laws clearly and rationally and to hold in check oppressive tax bureaucrats.

16 "Standing" is the legal term for a person's right to be the one who brings a complaint. In general, $A$ cannot sue when it is $B$ who has been damaged, even if $B$ does have the right to sue. A relatively easy nontransparent way to gut an apparently strict law is for the legislature to attach such severe requirements for standing that no one has the right to bring suit under it. For example, a government could enact a law saying that corporations which pollute can be sued for punitive damages of five million dollars per day, but require that the person bringing suit be a neighbor who has owned property next to the corporation for at least fifty years free and clear of any mortgage. If the law does not have 
Secretariat does not punish judges simply for favoring plaintiffs who challenge the government (Ramseyer and Rasmusen 1999). Third, the Secretariat does punish judges whose decisions are reversed on appeal by the higher courts, since accuracy is important if the courts are to correctly monitor the bureaucracy (Ramseyer and Rasmusen 1999). In all of this, the judges respond with a logic that reflects LDP interests: although they give the LDP-controlled national bureaucracy broad discretion, they narrowly cabin the discretion they allow local governments (which, as noted below, have often been controlled by the non-LDP opposition parties; Ramseyer 1999).

Injunctions against the government, however, can be decidedly non-routine. It is one thing to hold that a taxpayer owes only $X$ in back taxes rather than the $2 X$ dishonestly claimed by a bureaucrat trying to make his yearly quota. It is quite another to block government policy. Given that national bureaucrats answer to the cabinet, if LDP leaders want a national agency to stop doing action $Y$ they can simply tell it to stop, and fire the agency head if he refuses. For a court to order the agency to desist from doing $Y$ directly jeopardizes LDP-mandated policy in cases important enough that the elected officials could have intervened themselves. Given all this, one might plausibly suspect that a judge who readily enjoins the national government jeopardizes his career.

By the same logic, a judge would not face this threat for enjoining local governments. During the 1960s, the LDP increasingly lost control over these governments. By 1975 , only 12.5 percent of mayors had run on an exclusively LDP ticket. ${ }^{17}$ As a result, even if the Secretariat punished judges for enjoining LDP policy, we should not observe the punishment among judges who enjoined local governments. From the LDP's point of view, to enjoin the national government

restrictive standing rules, that is a sign that the legislature really means it to be enforced. For the Japanese law of standing, see Ramseyer and Nakazato (1998, ch. 8).

${ }^{17}$ Ramseyer and Rosenbluth (1993, p. 48 tab. 3.3). This was the kind of concern that led to the LDP leadership wishing to reposition the party away from the overrepresented rural districts. 
was to jeopardize policies important for national prosperity; to enjoin a local government was to protect the rule of law against creeping socialism.

[Insert Table 5 about here.]

2. The variables. -- To test these hypotheses, we first code all published administrative cases from 1961 to 1970 in which a petitioner demanded a preliminary injunction. We restrict ourselves to one decade to limit the potential length of time between multiple injunctions issued by any one judge and because injunctions are common enough that we can obtain a good-sized sample even over one decade. Judges seem to have issued fewer preliminary injunctions in recent years, for reasons that may be understandable once we report our findings. ${ }^{18}$

We drop unsigned opinions, judges not in the ZSKS, and judges without 1-1/2 years' experience before or 2-1/2 years' after the opinion. This leaves us with a sample of 130 judges. Where a judge has handled injunctive petitions over several years, we code his career by the most recent year in which he granted an injunction. Summary statistics appear in Table 5. Because we were able to locate only five opinions in which a higher court reversed the grant of an injunction, we do not include a variable dealing with reversals.

We define the following new variables( see summary statistics in Table 5):

NATIONAL_INJ_GRANTED: the number of petitions for preliminary injunctions against the national government granted by a judge. We use the number of times he enjoins the government (rather than a dummy variable) to capture how readily he uses the remedy.

NATIONAL_INJ_DENIED: the number of petitions for preliminary injunctions against the national government that a judge denied.

\footnotetext{
18 From 1971 through 1980, there were 20 reported district court opinions granting preliminary injunctions; from 1981 through 1997, there were 17.
} 
LOCAL_INJ_GRANTED: the number of petitions for preliminary injunctions against a local (municipal or prefectural) government that a judge granted.

LOCAL_INJ_DENIED: the number of petitions for preliminary injunctions against a local government that a judge denied.

[Insert Table 6 about here.]

3. The results. -- The results shown in Table 6 confirm that judges who enjoin the national government do indeed jeopardize their careers. The coefficient on NATIONAL_INJ_GRANTED in Regression (6.2) is negative and significant: judges who enjoin the national government receive fewer administrative responsibilities over the ensuing decade. This contrasts sharply with the fate of judges who deny injunctions. The coefficient on NATIONAL_INJ_DENIED is positive and significant in Regression (6.2), and negative and significant in Regression (6.1); judges who refuse injunctions against the national government receive additional administrative assignments and spend less time in branch offices. The results also confirm the predicted distinction between national and local bureaucrats. In both Regressions (6.1) and (6.2), the granting or denial of injunctions against local governments has no significant effect on the judge's career, as shown by tstatistics ranging from .06 to 1.04 .

Where significant, the coefficients on the control variables once more have the predicted signs. PRIOR_GOOD_JOBS positively affects POST_GOOD_JOBS: fast-track judges continue to receive fast-track administrative assignments. SENIORITY positively affects POST_GOOD_JOBS and negatively affects POST_BAD_JOBS: the more senior the judge, the more time he spends with administrative responsibilities and the less time in branch offices. FLUNKS negatively affects POST_GOOD_JOBS: the judges who failed the LRTI exam the most often were least likely to be trusted with administrative responsibilities. ELITE_COLLEGE affects 
POST_BAD_JOBS negatively and POST_GOOD_JOBS positively: judges from the Universities of Tokyo and Kyoto spent the least time in branch offices and the most time with administrative duties.

Note again, that this set of regressions is helpful in distinguishing different explanations for judicial behavior. It is not that the Secretariat is judicially conservative, unwilling to thwart the actions of elected officials or to intervene in political issues. Rather, it seems to be conservative with respect to the national government and neutral with respect to the local government -- much as the LDP might wish it to be.

\section{E. Prominent but Less Sensitive Cases:}

1. The issue. -- Ask now whether these phenomena reflect politicization, or just bureaucratization. ${ }^{19}$ Were judges punished because they favored the political opposition, or just because they refused to conform to the dictates of a large routinized organization? Judges who held the Self Defence Force unconstitutional could calculate the odds that the Supreme Court would reverse them, as could those who held the ban on door-to-door canvassing unconstitutional or those who held the early electoral districts unconstitutional. They knew they were flouting implicit orders from on high. They were mavericks, and nobody would expect a bureaucratic personnel office to treat mavericks well, politics or no politics. (Let us table the distinction between national and local government injunctions, for which it is hard to see any but a political logic.)

[Insert Table 7 about here.]

${ }^{19}$ Japanese courts are nothing if not bureaucratic. In confidential conversations with judges, we have heard that the performance variable many courts care most about is the classic bureaucratic one of a judge's docket clearance rate -- how fast paper passes through his courtroom. We have heard that one court, at least, circulates monthly reports to every judge of every other judge's docket clearance rate as a spur towards performance. 
2. Data and variables. -- To locate any apolitical bureaucratic bias against nonconformists, we examine the careers of judges reversed on appeal in two sets of politically less sensitive cases: those involving important but less salient constitutional issues, and those construing the even less political Commercial Code. Toward that end, we first identified the trial court judges involved in all Supreme Court opinions that appear in both a standard annotated version of the Constitution (Mohan 1997) and in a standard casebook on constitutional law (Abe and Ikeda 1989). We dropped (a) cases without a published, signed trial court opinion, (b) judges not in the ZSKS, and (c) judges without 1-1/2 years' experience before or 2-1/2 years' experience after the opinion. This leaves us with a sample of 75 judges from 46 cases. $^{20}$

Second, we produced a corresponding sample of trial judges in cases construing the Commercial Code that were appealed to the Supreme Court. ${ }^{21}$ To match them with the constitutional cases, we used commercial cases decided by the Supreme Court in the same years as the Court's opinions in our constitutional sample. Since there were more commercial cases than constitutional cases that needed matching, within the years of our constitutional sample we randomly chose a matching number of commercial cases. After dropping unsigned opinions and judges not in the ZSKS or lacking 1-1/2 years' experience before or 2-1/2 years' experience after the opinion, we had a commercial sample of 61 judges from 40 cases.

We construct the following new variables, summary statistics for which appear in Table 7 :

CON.AFF-AFF: 1 if a judge's opinion in the constitutional sample was affirmed by the High Court and then affirmed again by the Supreme Court; 0 otherwise.

\footnotetext{
${ }^{20}$ There is some overlap with the judges analyzed earlier in the paper, since we do not exclude Self Defence Force or malaportionment cases from this sample. See our further discussion of this below.

${ }^{21}$ Note that such a comparison would be more difficult for a study of the United States, because under our federal system, the federal Supreme Court decides most constitutional cases while state supreme courts decide most commercial law.
} 
CON.REV-REV: 1 if a judge's opinion in the constitutional sample was reversed by the High Court and then reversed again by the Supreme Court (i.e., the High Court reversal was in turn reversed); 0 otherwise.

CON.AFF-REV: 1 if a judge's opinion in the constitutional sample was affirmed by the High Court and then reversed by the Supreme Court (i.e., the High Court affirmance was reversed); 0 otherwise.

CON.REV-AFF: 1 if a judge's opinion in the constitutional sample was reversed by the High Court and then affirmed by the Supreme Court (i.e., the High Court reversal was affirmed); 0 otherwise.

COMM.AFF-AFF: 1 if a judge's opinion in the commercial sample was affirmed by the High Court and then affirmed again by the Supreme Court; 0 otherwise. This will be the omitted variable in the Table 9 regressions.

COMM.REV-REV: 1 if a judge's opinion in the commercial sample was reversed by the High Court and then reversed again by the Supreme Court; 0 otherwise.

COMM.AFF-REV: 1 if a judge's opinion in the commercial sample was affirmed by the High Court and then reversed by the Supreme Court; 0 otherwise.

COMM.REV-AFF: 1 if a judge's opinion in the constitutional sample was reversed by the High Court and then affirmed by the Supreme Court; 0 otherwise.

[Insert Table 8 about here.]

3. Results. -- In several ways, the results show a modestly (i.e., less pronounced than in the more controversial cases discussed above) political as well as a bureaucratic dynamic. First, as the negative coefficient on CON.AFF-AFF in regression (8.1) shows, a judge who is affirmed by both courts in a constitutional law case will tend to avoid branch office time. Moreover, he will be more 
likely to do so than a judge who is affirmed by both courts in a (generally less politically sensitive) commercial law case -- which is the ommited variable in this regression.

Second, as the positive coefficient on CON.REV-REV in (8.2) shows, a judge who is reversed by both courts in a constitutional case will spend more time in prestigious assignments. This is also consistent with our political-incentives theory -- for often (though not always) a judge who is reversed by the High Court but whose High Court reversal is then in turn reversed by the Supreme Court has effectively received the Supreme Court's blessing.

Third, as the positive coefficients on CON.AFF-REV and COM.AFF-REV in (8.3) show, a judge who is affirmed by the High Court but then reversed by the Supreme Court also spends more time in prestigious assignments. This too is consistent with our theory. The key to the puzzle is the fact that the High Court typically deals with issues of legal accuracy, while the Supreme Court is more likely to review issues of fundamental policy. Thus, where the High Court affirms a trial court, it has generally simply decided that the trial judge applied the extant law correctly. If the Supreme Court then reverses that affirmance, typically it is not second-guessing that decision; instead, it is signalling a major shift in legal direction. One would not expect the trial judge to be punished in such a case -- and the regressions indicate that he is not.

Again, where significant, the control variables lie in the predicted directions. PRIOR_GOOD_JOBS has a positive effect on POST_GOOD_JOBS, as does PRIOR_BAD_JOBS on POST_BAD_JOBS. Both SENIORITY and ELITE_COLLEGE have negative effects on POST_BAD_JOBS and positive effects on POST_GOOD_JOBS. $1^{\mathrm{ST}}$ _TOKYO affects POST_GOOD_JOBS positively.

Thus, in several samples of judges, we find evidence of careers being affected by politics, both in the number of unusually bad assignments a judge receives and in the number of unusually 
good assignments. Comparison of the summary statistics in Tables 1, 3, 5, and 7 shows that these samples are similar in some dimensions and different in others. The Preliminary Injunctions judges of Table 5 are the closest to the average judges in Japan, with lower means for PRIOR_GOOD_JOBS, $1^{\mathrm{ST}}$-TOKYO, and OPINIONS/YR and a higher mean for FLUNKS compared to the other three samples. The Malapportionment sample contains older and more distinguished judges, with a much higher mean for SENIORITY (23.01, compared with 13. 12, 10.99, and 9.42), higher means for PRIOR_GOOD_JOBS and OPINIONS/YR, and a lower mean for FLUNKS. This is what one might expect, since this type of lawsuit is decided in a High Court, and High Courts are staffed by older and better judges. The Article 9 and Prominent Opinions samples are intermediate in their summary statistics, but each has its own special features. We hope that by looking at several different groups of judges, our results are more robust than if we had simply aggregated all of our data. In the next section, however, we will run one regression that does take a more aggregate approach, exploring a measure of salary increase in a much larger sample of 501 judges.

\section{Judicial Pay:}

\section{A. Introduction:}

We conclude by exploring whether punishment against political nonconformists extends to salaries. During their first 10 years on the bench, Japanese judges climb through the 12 steps of the assistant judge pay scale -- as of 1989, a range from 190,600 to 405,600 yen per month. During the rest of their career, they move through another 9 steps -- from 494,000 yen (Step 8) to 912,000 (Step 3) to $1,115,000$ (Step 0). Although the Constitution protects judges from explicit pay cuts, the 
Secretariat need not promote all judges at the same rate. If unhappy with a judge's work, it need not promote him at all.

A judge's salary is confidential, but it does correlate with certain observable indices. Most importantly, according to some observers a judge can serve as sokatsu only when he reaches Step 3. If so, then the time from a judge's initial appointment to his first sokatsu assignment will reflect, if only imperfectly, the amount of time it took him to reach the Step 3 pay grade.

Accordingly, to test for pay discrimination, we regress the time it takes a judge to reach his first sokatsu appointment on his membership in the YJL and on several control variables. To control for unobservable differences among the cohorts, we further include dummy variables indicating the year in which a judge finished his legal education.

\section{B. The Data:}

For this test, we took as our starting point all judges hired between 1959 and 1968 (793 judges). We then made two important adjustments. ${ }^{22}$

First, we dropped those judges who held non-judicial postings (generally regarded as prestigious) in the 2 years before their first sokatsu posting. A judge in such a post could not have held sokatsu duties but might well have been at Step 3 already, having postponed that more mundane career step. If we included the time-to-first-sokatsu figures for these fast-track judges in our data base we would exaggerate the time required for promotion. ${ }^{23}$

\footnotetext{
${ }^{22}$ We also dropped judges who did not join the court within a year of graduating from the LRTI. In two cases, we did not have a judge's date of birth, and thus could not calculate FLUNKS. Accordingly, we used the mean for the group as a whole.

${ }^{23}$ In those rare cases where a judge served as chief judge before serving as soktatsu we treated his appointment to the chief judgeship as his sokatsu posting. Such an appointment is unambiguously higher than a sokatsu post.
} 
Of course, by dropping such judges entirely we bias our data in a different way. ${ }^{24}$ Since these judges were among the more successful in their cohort, by dropping them we exaggerate our estimate of the true time-to-sokatsu for judges with their characteristics. Other research shows that YJL members did not receive these prestigious administrative responsibilities as often as their peers (Ramseyer and Rasmusen 1997). As a result, by dropping these star judges we drop non-YJL judges disproportionately. We thereby understate the success of the non-YJL judges and concomitantly bias our data against finding anti-YJL discrimination. ${ }^{25}$

Second, we had somehow to deal with judges who never obtained a sokatsu appointment. The true value of time-to-first-sokatsu for them is infinity, but using that value obviously would distort the analysis. Our first adjustment to deal with this was to drop a group of 164 judges, 23.8 per cent of whom were YJL members judges, who (a) never obtained a sokatsu appointment and (b) quit or died before the mean time-to-first-sokatsu for the rest of the group, 20.41 years. Our second adjustment was that if a judge quit or died after 20.41 years without a sokatsu appointment, ${ }^{26}$ we kept him in the dataset but treated his death or resignation as his time of first sokatsu appointment. We applied this procedure to 83 judges, 33.7 per cent of whom were YJL members. ${ }^{27}$

${ }^{24}$ Nonetheless, we chose to drop the judges rather than to keep them in and include their time-to-first-sokatsu, even though both procedures biased the sample in the same direction, because dropping them entirely would make it hardest to find statistically significant evidence of discrimination.

${ }^{25}$ A hypothetical may help to illustrate the bias problem. Suppose that 90 percent of non-YJL judges get fasttrack administrative appointments and early pay raises, but no YJL judges do, that those administrative appointees all become sokatsu some years later, and that YJL judges indeed get their pay raises much later on average. If we retained the fast-trackers, we would conclude that being in the YJL helped in getting an early pay raise, since the YJL judges would make sokatsu much earlier on average. If we omitted the fast-trackers, we would be left with the YJL judges and just the worst 10 percent of the non-YJL judges, and we would find little if any difference in their rate of pay increase. Since it is not true that 90 percent of non-YJL judges are on the fast track, the bias is not so large, but it still exists.

${ }^{26}$ We include here those judges who still did not have a sokatsu appointment as of 1997, the last year for which the ZSKS includes data.

${ }^{27}$ We computed the mean values of the variables for the 294 judges we dropped for the various reasons, to get some idea of how they compare with the 501 judges we retained and whose descriptive statistics are shown in Table 9. For the Retained and Dropped judges the values of YJL were .28 and .22 ; the values of $1^{\text {st }}$-TOKYO were .10 and .24 ; the values of ELITE-COLLEGE were .32 and .38; and the values of FLUNKS were 4.83 and 4.84 . Thus, the main difference is that the dropped judges include many more fast-trackers who started with Tokyo postings-- as one would 
Although these last two adjustments also bias our data, they again bias it against finding anti-YJL discrimination. If a judge quit during the first 20 years of his career, then the fact that he quit tells us little about how well he was doing. If he quit later, however, when many of his peers were serving as sokatsu but he was not, we can deduce that he was a relatively unsuccessful judge. By treating his resignation as equivalent to a sokatsu appointment, we overstate his professional success. Because he never received a sokatsu appointment, the length of his career will necessarily be shorter (or equal to) the length of time it would have taken him to reach sokatsu had he not quit. Interestingly, this group of unsuccessful judges included a disproportionately high fraction of YJL members (33.7 percent). By making this adjustment, therefore, we will tend to underestimate the time-to-first-sokatsu for YJL members.

\section{The Variables:}

Summary statistics appear in Table 9, including a correlation matrix. As our dependent variable is not censored, we can use ordinary least squares for this regression. We introduce only one new variable,

TIME2SOK: the year a judge first received a sokatsu appointment, less the year he graduated from the LRTI -- subject to the adjustments described above.

[Insert Table 9 about here.]

D. The Results:

expect from our retention criterion. Heckman and Robb (1985) initiated a literature in labor econometrics on how to deal with people who exit a labor force nonrandomly. We have left the use of those self-selection techniques on this data for future research. 
We report our results in the third panel of Table 9. Notably, the coefficient on YJL is positive and significant: judges who joined the YJL in the 1960s received their first sokatsu assignment about a year later than their peers. If, as observers claim, a sokatsu appointment signals promotion to Step 3 on the pay scale, then YJL members progressed up the pay scale significantly more slowly than their peers.

As one might expect, the coefficient on $1^{\text {st }}-\mathrm{TOKYO}$ is negative and significant: judges who began their careers at the Tokyo District Court climbed the pay scale faster than others. Although the coefficients on ELITE_COLLEGE and FLUNK are not significant, recall that $1^{\text {st }}$-TOKYO indirectly incorporates their impact on judicial careers.

\section{Conclusions}

With newly assembled data and a multivariate approach, we ask whether Japanese judges who flout the ruling party in a variety of politically charged cases do worse in their careers. They do indeed. Lower-court judges defer to the LDP for a simple reason: those who do receive better career assignments. For the institutional and political logic to this phenomenon, we refer readers to other work (e.g., Ramseyer, 1994, 1998, 1999). Here, we limit ourselves to the new empirical results. For example, take the constitutionality of the Self Defence Force: judges who sided with the LDP on the SDF received better assignments than those who did not. Take the apportionment debate: those who held apportionment schemes valid during the time when the LDP relied on overrepresented rural districts did better than those who did not. Or suppose a judge faced demands for injunctions against a national agency: if he granted them, he was likely to do worse than if he denied them. The potential punishment can even involve pay: apparently, judges who joined the 
leftist YJL climbed the pay scale significantly more slowly than their politically more conservative peers.

As always with statistical work, one should not take the results as final. Consistently, however, the multivariate regressions suggest, at statistically significant levels, that judicial independence in Japan has real limits. In politically sensitive cases, judges seem to indulge their political preferences at their peril. Should they flout the preferences of the LDP, they potentially pay with their careers.

Whether this is good or bad is a different question than whether it happens, and a question beyond the scope of this article. Perhaps it is good that Japan has an army and U.S. bases, that rural voters had extra clout in the first three postwar decades, that socialist mayors but not capitalist ministries were restrained by the judiciary, that policies were in place to help incumbents in elections, that leftwing judges earned less, and that, in general, judges who acted in arbitrary ways following their own non-LDP tastes knew they would be punished. Perhaps all this has been a good thing, perhaps not. Judicial independence is not an obvious good, and we take no position on that debate. Instead, we simply describe several of the ways that the institutional structure of the Japanese courts has reflected a distinctly political dynamic. 
Table 1:

Article 9 (Military)-- Summary statistics

\begin{tabular}{lcccc} 
& Minimum & Median & Mean & Maximum \\
\hline POST_GOOD_JOBS & 0 & 0.39 & 0.44 & 1 \\
POST_BAD_JOBS & 0 & 0 & 0.17 & 0.92 \\
UNCONSTITUTIONAL & 0 & 0 & 0.12 & 1 \\
PRIOR_GOOD_JOBS & 0 & 0 & 0.22 & 0.93 \\
PRIOR_BAD_JOBS & 0 & 0 & 0.09 & 0.8 \\
SENIORITY & 2 & 11 & 13.12 & 29 \\
FLUNKS & 0 & 3 & 3.84 & 12 \\
ELITE_COLLEGE & 0 & 1 & 0.56 & 1 \\
IT_TOKYO & 0 & 0 & 0.24 & 1 \\
OPINIONS/YR & 0 & 2.23 & 3.36 & 29.75 \\
YJL & 0 & 0 & 0.12 & 1
\end{tabular}

Note: $N=50$. The times spent in good and in bad jobs do not sum to 1 , because mediocre jobs are an omitted category.

\section{Table 2:}

Article 9 (Military) -- The Effect of Opinions on Careers

$$
\text { (2.1) (2.2) }
$$

Dependent variable:

POST_BAD_JOBS POST_GOOD_JOBS

\begin{tabular}{|c|c|c|c|c|}
\hline UNCONSTITUTIONAL & -.028 & $(0.14)$ & -.397 & $(1$ \\
\hline PRIOR_GOOD_JOBS & & & .729 & 12 \\
\hline PRIOR_BAD_JOBS & -.073 & $(0.24)$ & & \\
\hline SENIORITY & .011 & $(1.21)$ & .019 & (1 \\
\hline FLUNKS & .026 & $(1.44)$ & -.018 & \\
\hline ELITE_COLLEGE & -.256 & $(2.13) \star \star$ & .201 & \\
\hline $1^{\mathrm{ST}}$-TOKYO & .071 & $(0.45)$ & .231 & \\
\hline OPINIONS/YR & -.100 & $(2.41) \star \star$ & -.023 & \\
\hline YJL & .140 & $(0.55)$ & .099 & \\
\hline Intercept & .177 & $(0.99)$ & .061 & 10 \\
\hline Pseudo $\mathrm{R}^{2}$ : & \multicolumn{2}{|c|}{0.46} & \multicolumn{2}{|c|}{0.55} \\
\hline Standard error: & \multicolumn{2}{|c|}{0.29} & \multicolumn{2}{|c|}{0.31} \\
\hline $\begin{array}{l}\text { Notes: } N=50 \text {. These are tobit regressions } \\
\text { followed by the absolute value of } t \text {-statistics in } \\
\text { regressions include dummies for the } 3 \text { judges with } \\
\text { coefficients are not reported here. } \\
\text { * indicates significance at the } 5 \text { percent } \\
\text { * indicates significance at the } 10 \text { percent }\end{array}$ & $\begin{array}{l}\text { is. The } \\
\text { in paren } \\
\text { h multi } \\
\text { it level } \\
\text { it level }\end{array}$ & $\begin{array}{l}\text { coefficient } \\
\text { thesis. The } \\
\text { ple opinior } \\
\text { for a two }\end{array}$ & $\begin{array}{l}\text { ts are } \\
\text { ese } \\
\text { ns, but }\end{array}$ & the \\
\hline
\end{tabular}


Table 3:

Malapportionment -- Summary Statistics

\begin{tabular}{|c|c|c|c|c|}
\hline & Minimum & Median & Mean & Maximum \\
\hline POST_GOOD_JOBS & 0 & 0.64 & 0.60 & 1 \\
\hline POST_BAD_JOBS & 0 & 0 & 0.10 & 1 \\
\hline INVALID $\leq 73$ & 0 & 0 & 0.02 & 1 \\
\hline INVALID $\geq 74$ & 0 & 0 & 0.31 & 1 \\
\hline INVALID $\leq 83$ & 0 & 0 & 0.07 & 1 \\
\hline INVALID $\geq 84$ & 0 & 0 & 0.26 & 1 \\
\hline INVALID . REV & 0 & 0 & 0.04 & 1 \\
\hline VALID . REV & 0 & 0 & 0.01 & 1 \\
\hline PRIOR_GOOD_JOBS & 0 & 0.31 & 0.39 & 1 \\
\hline PRIOR_BAD_JOBS & 0 & 0 & 0.12 & 0.73 \\
\hline SENIORITY & 5 & 24 & 23.01 & 39 \\
\hline FLUNKS & 0 & 2 & 3.00 & 9 \\
\hline ELITE_COLLEGE & 0 & 0 & 0.46 & 1 \\
\hline $1^{\mathrm{ST}}{ }_{\mathrm{TOKYO}}$ & 0 & 0 & 0.20 & 1 \\
\hline OP INIONS / YR & 0 & 4.85 & 5.88 & 22.22 \\
\hline YJL & 0 & 0 & 0.12 & 1 \\
\hline
\end{tabular}


Table 4: Malapportionment -- The Effect of Opinions on Careers

\begin{tabular}{|c|c|c|c|c|c|c|}
\hline $\begin{array}{l}\text { Dependent } \\
\text { variable: }\end{array}$ & $\begin{array}{c}(4.1) \\
\mathrm{POST}_{-} \\
\mathrm{BAD}_{2} \mathrm{JOB}\end{array}$ & $\begin{array}{c}(4.2) \\
\text { POST_- } \\
\text { GOOD_JOB }\end{array}$ & $\begin{array}{l}(4.3) \\
\text { POST_ } \\
\text { BAD_JOB }\end{array}$ & $\begin{array}{c}(4.4) \\
\text { POST_ } \\
\text { GOOD_JOB }\end{array}$ & $\begin{array}{l}(4.5) \\
\text { POST_- } \\
\text { BAD_JOB }\end{array}$ & $\begin{array}{c}(4.6) \\
\text { POST_ } \\
\text { GOOD_JOB }\end{array}$ \\
\hline INVALID $\leq 73$ & $\begin{array}{l}1.36 * \star \\
(2.90)\end{array}$ & $\begin{array}{l}-.710 * \star \\
(2.15)\end{array}$ & & & & \\
\hline INVALID $\geq 74$ & $\begin{array}{l}-.018 \\
(0.10)\end{array}$ & $\begin{array}{l}.018 \\
(0.20)\end{array}$ & & & & \\
\hline INVALID $\leq 83$ & & & $\begin{array}{l}.607 \star \star \\
(2.24)\end{array}$ & $\begin{array}{l}-.243 \\
(1.41)\end{array}$ & & \\
\hline INVALID $\geq 84$ & & & $\begin{array}{l}-.173 \\
(0.85)\end{array}$ & $\begin{array}{l}.036 \\
(0.34)\end{array}$ & & \\
\hline INVALID . REV & & & & & $\begin{array}{l}.980 * \star \\
(2.67)\end{array}$ & $\begin{array}{l}-.380 * \\
(1.70)\end{array}$ \\
\hline VALID.REV & & & & & $\begin{array}{l}.448 \\
(0.89)\end{array}$ & $\begin{array}{l}-.199 \\
(0.51)\end{array}$ \\
\hline PRIOR_GOOD_JOBS & & $\begin{array}{l}-.053 \\
(0.25)\end{array}$ & & $\begin{array}{l}-.016 \\
(0.77)\end{array}$ & & $\begin{array}{l}-.026 \\
(0.12)\end{array}$ \\
\hline PRIOR_BAD_JOBS & $\begin{array}{l}-.129 \\
(0.36)\end{array}$ & & $\begin{array}{r}-.183 \\
(0.47)\end{array}$ & & $\begin{array}{c}-.258 \\
(0.67)\end{array}$ & \\
\hline SENIORITY & $\begin{array}{l}.010 \\
(0.96)\end{array}$ & $\begin{array}{l}.020 * \star \\
(2.01)\end{array}$ & $\begin{array}{l}.015 \\
(1.19)\end{array}$ & $\begin{array}{l}.020 * \star \\
(2.01)\end{array}$ & $\begin{array}{l}.013 \\
(1.09)\end{array}$ & $\begin{array}{l}.020 * \star \\
(2.01)\end{array}$ \\
\hline FLUNKS & $\begin{array}{l}.00054 \\
(0.02)\end{array}$ & $\begin{array}{l}-.017 \\
(0.88)\end{array}$ & $\begin{array}{c}-.0098 \\
(0.30)\end{array}$ & $\begin{array}{l}-.016 \\
(0.78)\end{array}$ & $\begin{array}{l}-.014 \\
(0.42)\end{array}$ & $\begin{array}{l}-.016 \\
(0.78)\end{array}$ \\
\hline ELITE_COLLEGE & $\begin{array}{l}-.389 * \star \\
(2.21)\end{array}$ & $\begin{array}{l}.135 \\
(1.35)\end{array}$ & $\begin{array}{l}-.276 \\
(1.55)\end{array}$ & $\begin{array}{l}.111 \\
(1.09)\end{array}$ & $\begin{array}{l}-.339 \star \\
(1.90)\end{array}$ & $\begin{array}{l}.120 \\
(1.19)\end{array}$ \\
\hline $1^{\mathrm{ST}}$ _TOKYO & $\begin{array}{l}.191 \\
(0.92)\end{array}$ & $\begin{array}{l}-.107 \\
(0.84)\end{array}$ & $\begin{array}{l}.218 \\
(0.98)\end{array}$ & $\begin{array}{l}-.111 \\
(0.86)\end{array}$ & $\begin{array}{l}.241 \\
(1.14)\end{array}$ & $\begin{array}{l}-.108 \\
(0.86)\end{array}$ \\
\hline OPINIONS/YR & $\begin{array}{l}-.084 * \star \\
(2.51)\end{array}$ & $\begin{array}{l}.031 * \star \\
(2.23)\end{array}$ & $\begin{array}{l}-.096 \star \star \\
(2.35)\end{array}$ & $\begin{array}{l}.027 \star \\
(1.95)\end{array}$ & $\begin{array}{l}-.100 * \star \\
(2.49)\end{array}$ & $\begin{array}{l}.029 * \star \\
(2.08)\end{array}$ \\
\hline YJL & $\begin{array}{l}-.174 \\
(0.64)\end{array}$ & $\begin{array}{l}.030 \\
(0.21)\end{array}$ & $\begin{array}{l}-.116 \\
(0.39)\end{array}$ & $\begin{array}{l}.029 \\
(0.20)\end{array}$ & $\begin{array}{l}-.131 \\
(0.46)\end{array}$ & $\begin{array}{l}0.31 \\
(0.22)\end{array}$ \\
\hline Intercept & $\begin{array}{l}.0029 \\
(0.01)\end{array}$ & $\begin{array}{c}-.036 \\
(0.18)\end{array}$ & $\begin{array}{l}-.069 \\
(0.23)\end{array}$ & $\begin{array}{l}-.043 \\
(0.20)\end{array}$ & $\begin{array}{l}.0060 \\
(0.02)\end{array}$ & $\begin{array}{l}.047 \\
(0.23)\end{array}$ \\
\hline Pseudo $\mathrm{R}^{2}$ : & 0.33 & 0.30 & 0.31 & 0.29 & 0.33 & 0.29 \\
\hline $\begin{array}{l}\text { Standard error: } \\
\text { Censoring } \\
(y<0, \text { unc., } y>1)\end{array}$ & $\begin{array}{l}0.45 \\
71,24,1)\end{array}$ & $\begin{array}{l}0.36 \\
3,64,19)\end{array}$ & $\begin{array}{l}0.48 \\
71,24,1)\end{array}$ & $\begin{array}{l}0.37 \\
3,64,19)\end{array}$ & $\begin{array}{l}0.47 \\
(71,24,1)\end{array}$ & $\begin{array}{l}0.37 \\
(13,64,19)\end{array}$ \\
\hline $\begin{array}{l}\text { Notes: } N=97 \text {. } \\
\text { absolute value of } t \\
\text { with multiple opini } \\
\text { che } 5 \text { percent level }\end{array}$ & $\begin{array}{l}\text { ese are } \\
\text { tistics } \\
\text { were est } \\
\text { a two-s. }\end{array}$ & $\begin{array}{l}\text { t regress } \\
\text { arenthesi } \\
\text { ed but ar } \\
\text { test. }\end{array}$ & $\begin{array}{l}\text { hs. The } \\
\text { Coeffici } \\
\text { not repor } \\
\text { ndicates }\end{array}$ & $\begin{array}{l}\text { for dum } \\
\star \star \\
\text { ificance }\end{array}$ & $\begin{array}{l}\text { Iollowed } \\
\text { for the } \\
\text { the } 10 \mathrm{p}\end{array}$ & $\begin{array}{l}\text { the } \\
\text { judges } \\
\text { ance at } \\
\text { ent leve }\end{array}$ \\
\hline
\end{tabular}


Table 5:

Preliminary Injunctions --

Summary Statistics

\begin{tabular}{|c|c|c|c|c|}
\hline & Minimum & Median & Mean & Maximum \\
\hline POST_GOOD_JOBS & 0 & 0.07 & 0.26 & 1 \\
\hline POST_BAD_JOBS & 0 & 0.09 & 0.21 & 0.9 \\
\hline NATIONAL_INJ_GRANTED & 0 & 0 & 0.37 & 3 \\
\hline NATIONAL_INJ_DENIED & 0 & 0 & 0.5 & 7 \\
\hline LOCAL_INJ_GRANTED & 0 & 0 & 0.4 & 4 \\
\hline LOCAL_INJ_DENIED & 0 & 0 & 0.40 & 2 \\
\hline PRIOR_GOOD_JOBS & 0 & 0 & 0.06 & 0.75 \\
\hline PRIOR_BAD_JOBS & 0 & 0 & 0.11 & 0.81 \\
\hline SENIORITY & 2 & 8 & 9.42 & 22 \\
\hline FLUNKS & 0 & 4 & 4.32 & 16 \\
\hline ELITE_COLLEGE & 0 & 0 & 0.46 & 1 \\
\hline $1^{\mathrm{ST}}{ }_{\mathrm{TOKYO}}$ & 0 & 0 & 0.09 & 1 \\
\hline OPINIONS / YR & 0 & 1.49 & 2.07 & 10.67 \\
\hline YJL & 0 & 0 & 0.12 & 1 \\
\hline
\end{tabular}


Table 6:

Preliminary Injunctions --

The Effect of Opinions on Careers

\begin{tabular}{|c|c|c|}
\hline $\begin{array}{l}\text { Dependent } \\
\text { variable: }\end{array}$ & $\begin{array}{l}(6.1) \\
\text { POST_- } \\
\text { BAD_JOBS }\end{array}$ & $\begin{array}{l}(6.2) \\
\text { POST_- } \\
\text { GOOD_JOBS }\end{array}$ \\
\hline \#NATIONAL_INJ_GRANTED & $-.04 \quad(0.52)$ & $-.12(1.70) *$ \\
\hline \#NATIONAL_INJ_DENIED & $-.13(2.03) * \star$ & $(1.93) *$ \\
\hline \#LOCAL_INJ_GRANTED & $.05(0.90)$ & $-.003(0.06)$ \\
\hline \#LOCAI_INJ_DENIED & $.08 \quad(1.04)$ & $.05(0.68)$ \\
\hline PRIOR_GOOD_JOBS & & $1.07(4.18) * *$ \\
\hline PRIOR_BAD_JOBS & $.21(0.94)$ & \\
\hline SENIORITY & $-.04(4.18) * *$ & $.04(5.59) * \star$ \\
\hline FLUNKS & $.009(0.70)$ & $-.04(3.07) * \star$ \\
\hline ELITE_COLLEGE & $-.16(1.96) *$ & $.13(1.78) *$ \\
\hline $1^{\mathrm{ST}}$ TOKYO $^{\mathrm{ST}}$ & $-.11(0.79)$ & $.06(0.44)$ \\
\hline OP INIONS/YR & $.02 \quad(0.77)$ & $-.03(1.05)$ \\
\hline YJL & $.03 \quad(0.28)$ & $-.12(0.91)$ \\
\hline Intercept & $.37(3.24) * \star$ & $-.22(2.03) \star \star$ \\
\hline $\begin{array}{l}\text { Pseudo } R^{2} \text { : } \\
\text { Standard error } \\
\text { Censoring }(y<0, \text { unc, } y>1) \\
N=130\end{array}$ & $\begin{array}{l}0.22 \\
0.37 \\
: \quad(64,66,0)\end{array}$ & $\begin{array}{l}0.44 \\
0.34 \\
(61,65,4)\end{array}$ \\
\hline $\begin{array}{l}\text { Notes: These are tobit } \\
\text { of t-statistics in par } \\
* * \text { indicates signific } \\
\text { * indicates significa }\end{array}$ & $\begin{array}{l}\text { t regressions. } \\
\text { renthesis. } \\
\text { cance at the } 5 \mathrm{p} \\
\text { ance at the } 10 \mathrm{p}\end{array}$ & $\begin{array}{l}\text { The coefficients are followed by the absolute } \\
\text { ercent level for a two-sided test. } \\
\text { ercent level. }\end{array}$ \\
\hline
\end{tabular}


Table 7:

Prominent Opinions by Trial Judges --

Summary statistics

\begin{tabular}{|c|c|c|c|c|}
\hline & Minimum & Median & Mean & Maximum \\
\hline POST_GOOD_JOBS & 0 & 0.30 & 0.34 & 1 \\
\hline POST_BAD_JOBS & 0 & 0.16 & 0.20 & 1 \\
\hline $\begin{array}{r}\text { CONSTITUTIONAL } \\
\text { CON.AFF-AFF } \\
\text { CON.REV-REV } \\
\text { CON.AFF-REV } \\
\text { CON.REV-AFF }\end{array}$ & $\begin{array}{l}0 \\
0 \\
0 \\
0 \\
0\end{array}$ & $\begin{array}{l}1 \\
0 \\
0 \\
0 \\
0\end{array}$ & $\begin{array}{l}0.54 \\
0.15 \\
0.10 \\
0.12 \\
0.17\end{array}$ & $\begin{array}{l}1 \\
1 \\
1 \\
1 \\
1\end{array}$ \\
\hline $\begin{array}{l}\text { COMMERCIAL } \\
\text { COMM.AFF-AFE } \\
\text { COMM.REV-REV } \\
\text { COMM.AFF-REV } \\
\text { COMM. REV-AFF }\end{array}$ & $\begin{array}{l}0 \\
0 \\
0 \\
0 \\
0\end{array}$ & $\begin{array}{l}0 \\
0 \\
0 \\
0 \\
0\end{array}$ & $\begin{array}{l}0.46 \\
0.21 \\
0.04 \\
0.07 \\
0.13\end{array}$ & $\begin{array}{l}1 \\
1 \\
1 \\
1 \\
1\end{array}$ \\
\hline PRIOR_GOOD_JOBS & 0 & 0 & 0.12 & 1 \\
\hline PRIOR_BAD_JOBS & 0 & 0 & 0.15 & 1 \\
\hline SENIORITY & 2 & 8.50 & 10.99 & 33 \\
\hline FLUNKS & 0 & 3 & 3.70 & 13 \\
\hline ELITE_COLLEGE & 0 & 1 & 0.51 & 1 \\
\hline $1^{\mathrm{ST}}{ }_{\mathrm{TOKYO}}$ & 0 & 0 & 0.27 & 1 \\
\hline OPINIONS/YR & 0 & 1.75 & 3.02 & 17.45 \\
\hline YJL & 0 & 0 & 0.11 & 1 \\
\hline
\end{tabular}


Table 8:

Prominent Opinions by Trial Judges --

The Effect of Opinions on Careers

(8.1)

Dependent var.:

POST_BAD_JOBS

(8.2)

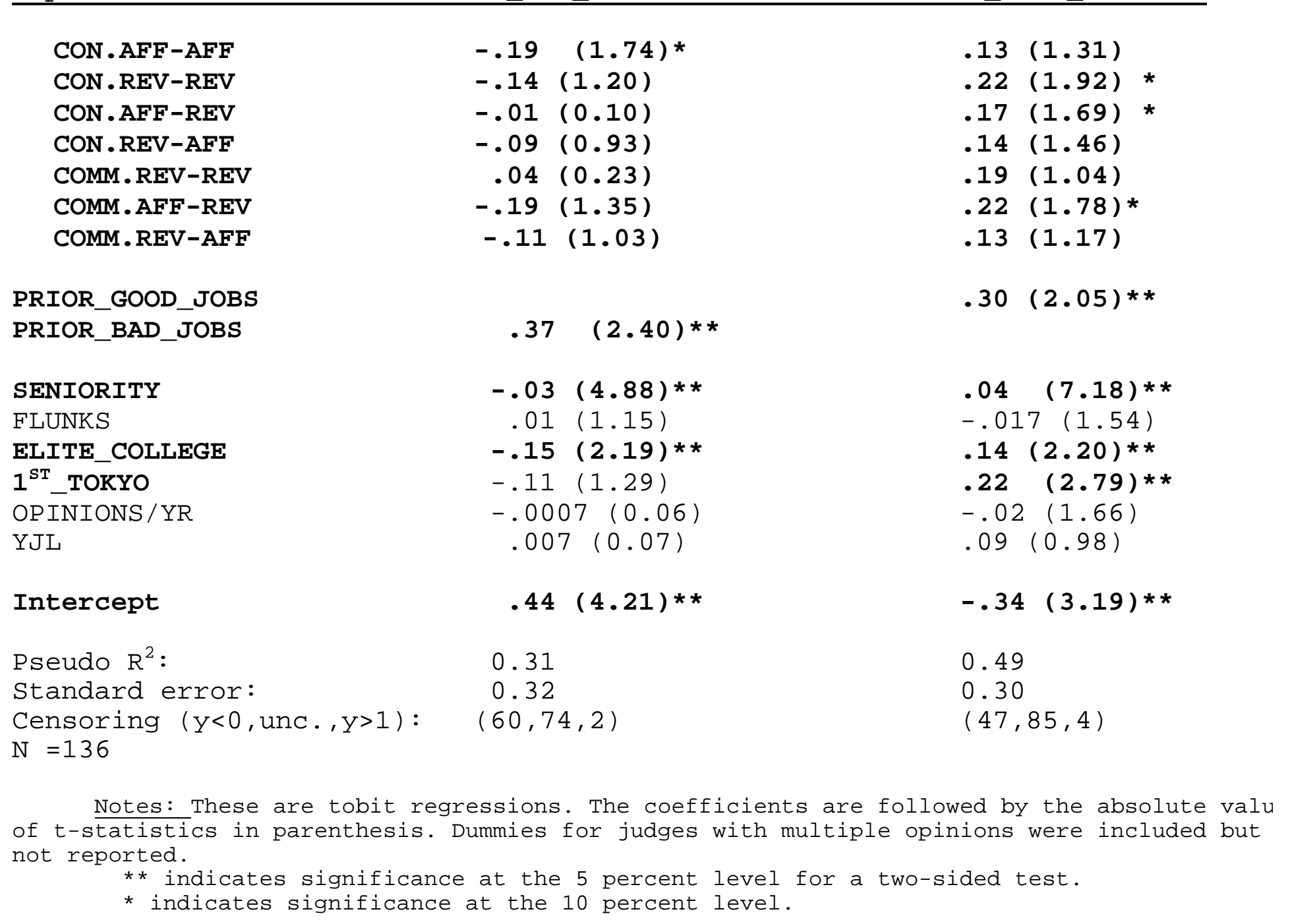


Table 9:

1959-1968 Judges: Time to Promotion to Sokatsu

\begin{tabular}{lrrrr} 
& Minimum & Median & Mean & Maximum \\
\hline TIME2SOK & 11 & 21 & 21.71 & 37 \\
YJL & 0 & 0 & 0.28 & 1 \\
1ST_TOKYO & 0 & 0 & 0.10 & 1 \\
FLUNKS & 0 & 4 & 4.83 & 18 \\
ELITE_COLLEGE & 0 & 0 & 0.32 & 1
\end{tabular}

\section{CORRELATIONS}

$\begin{array}{lcrrrr} & \text { TIME2SOK } & \text { YJL } & 1^{\text {ST }} \text { _TOKYO } & \text { FLUNKS } & \text { ELITE_COLLEGE } \\ \text { TIME2SOK } & 1.00 & & & & \\ \text { YJL } & .05 & 1.00 & & & \\ \text { 1 }^{\text {ST_TOKYO }} & -.04 & .01 & 1.00 & & \\ \text { FLUNKS } & .05 & -.12 & -.23 & 1.00 & \\ \text { ELITE_COLLEGE } & -.03 & .04 & .25 & -.23 & 1.00\end{array}$

Dependent Variable: TIME2SOK

YJL

1ST_TOKYO

FLUNKS

ELITE_COLLEGE

Intercept

Adjusted $\mathrm{R}^{2}$ :

$\mathrm{N}=501$
$.919(1.71)$ *

$-1.383(1.72)$ *

$.014(0.19)$

$.086(0.17)$

$22.905(29.20) * *$

0.09

Notes: This is an OLS regression. The coefficients are followed by the absolute value of t-statistics in parentheses. Dummies for the year the judges were hired were included but not reported.

** indicates significance at the 5 percent level for a two-sided test. * indicates significance at the 10 percent level. 


\section{REFERENCES}

Abe, Teruya and Masaaki Ikeda, eds. 1989. Shinpan: Kenpo hanrei [New Edition: Constitutional Cases]. Tokyo: Yuhikaku.

Auer, James E. 1993. “Article 9: Renunciation of War.” In Japanese Constitutional Law, eds. Percy R. Luney, Jr. and Kazuyuki Takahashi. Tokyo: University of Tokyo Press, 1993..

Beer, Lawrence W. 1996. “Japan's Constitutional Law, 1945-1990.” In The Constitutional Case Law of Japan, 1970 through 1990, eds. Lawrence W. Beer and Hiroshi Itoh. Seattle: University of Washington Press.

Ferejohn, John. 1995. "Law, Legislation, and Positive Political Theory." In Modern Political Economy: Old Topics, New Directions, eds. Jeffrey S. Banks \& Eric A. Hanushek. Cambridge: Cambridge University Press.

Haley, John Owen. 1995. "Judicial Review in Japan Revisited.” Law in Japan 25: 1.

Haley, John Owen. 1998. The Spirit of Japanese Law. Athens: University of Georgia Press.

Heckman, James, and Richard Robb. 1985. "Alternative Methods for Evaluating the Impact of Interventions: An Overview." Journal of Econometrics 30: 239-267.

Kashimura, Shiro. 1991. "Rodo jiken ni okeru saibankan no keireki to hanketsu [The Careers and Opinions of Judges in Labor Cases].” Kobe hogaku zasshi 41: 325.

McCubbins, Mathew D., and Thomas Schwartz. 1984. "Congressional Oversight Overlooked: Police Patrols versus Fire Alarms." American Journal of Political Science 28: 165.

Miyazawa, Setsuo. 1991. "Administrative Control of Japanese Judges." In Law and Technology in the Pacific Community, ed., Philip S.C. Lewis. Boulder: Westview Press.

Mohan roppo [Annotated Statutory Compilation]. 1997. Tokyo: Sanseido.

Netto 46. 1995. Saibankan ni narenai riyu [The Reason They Cannot Become Judges]. Tokyo: Aoki shoten.

Nihon minshu horitsuka kyokai, ed. 1998. Zen saibankan keireki soran: Dai san ban [Biographical Information on All Judges: $3 d$ Edition]. Tokyo: Konin sha (ZSKS).

Okudaira, Yasuhiro. 1993. "Forty Years of the Constitution and Its Various Influences: Japanese, American and European.” In Japanese Constitutional Law, eds. Percy R. Luney, Jr. and Kazuyuki Takahashi. Tokyo: University of Tokyo Press, 1993. P. 20.

Ramseyer, J. Mark. 1994. "The Puzzling (In)dependence of the Courts: A Comparative Approach." Journal of Legal Studies 23: 721.

Ramseyer, J. Mark. 1998. “Judicial Independence." In The New Palgrave Dictionary of Economics and the Law. London: Macmillan. 
Ramseyer, J. Mark. 1999. "Rethinking Administrative Guidance.” In Finance, Development and Competition in Japan: Essays in Honor of Hugh Patrick, eds. Masahiko Aoki \& Gary Saxonhouse. London: Oxford University Press.

Ramseyer, J. Mark, and Minoru Nakazato. 1998. Japanese Law: An Economic Approach. Chicago: University of Chicago Press.

Ramseyer, J. Mark, and Eric B. Rasmusen. 1997. "Judicial Independence in a Civil Law Regime: The Evidence from Japan." Journal of Law, Economics \& Organization 13: 259.

Ramseyer, J. Mark, and Eric B. Rasmusen. 1998. Why Is the Japanese Conviction Rate so High? (Working Paper, John M. Olin Center for Law, Economics, and Business, Harvard Law School).

Ramseyer, J. Mark, and Eric B. Rasmusen. 1999. "Why the Japanese Taxpayer Always Loses.” Southern California Law Review 72: 571-95.

Ramseyer, J. Mark, and Frances McCall Rosenbluth. 1993. Japan's Political Marketplace. Cambridge: Harvard University Press.

Sakaguchi, Tokuo. 1988. "Saibankan ni taisuru ninchi yakushoku 'sabetsu' ni tsuite [Regarding the 'Discrimination' Against Judges in Location and Official Responsibilities]." [Osaka bengoshi kai] Shiho mondai taisaku nyusu 5: 4.

Shiso undo kenkyu sho, ed. 1969. Osorubeki saiban [Fearsome Trials]. Tokyo: Zenbo sha.

Tomatsu, Hidenori. 19xx. "Equal Protection of the Law." In Japanese Constitutional Law, eds. Percy R. Luney, Jr. and Kazuyuki Takahashi. Tokyo: University of Tokyo Press, 1993.

Tsukahara, Eiji. 1991. "Saibankan keireki to saiban kodo [The Relationship Between a Judge's Career and His Opinions]." Ho shakai gaku 43: 46.

Witt, Elder. 1990. Congressional Quarterly's Guide to the U.S. Supreme Court, 2d ed.

ZSKS. See Nihon minshu. 